\title{
群馬県下における飲料水と斑状歯の実体調査研究（I ）
}

\author{
群馬県衛生研究所 滝島常雄, 木島敬二, 浅井久子 \\ 群馬県沼田保健所 斎藤 実
}

群䭴県の山岳地带吾妻郡抢よび利根郡は以前より斑状 歯の羅患率がたかいといわれていだ。とくに利根郡下 赤城山北面, 武尊山南面执よびそこを流れる片品川の上 流にその䍜患率が高いといわれている。著者等は両部下 中学二年生全員を対照汇調查を行い, 現地調查と使用飲 料水扣よび河川水などの水質分析を実施してこれを追究 した。

表 1 利根郡および吾妻郡の斑状歯罹患状洗

\begin{tabular}{|c|c|c|c|c|c|c|c|c|c|c|}
\hline & \multirow{2}{*}{$\begin{array}{l}\text { 中 } \\
\text { 学 } \\
\text { 校 }\end{array}$} & \multirow{2}{*}{ 人員 } & \multirow{2}{*}{$\begin{array}{l}\text { 羅 } \\
\text { 患 } \\
\text { 数 }\end{array}$} & & \multicolumn{3}{|c|}{ 男 于 } & \multicolumn{3}{|c|}{ 子 } \\
\hline & & & & & 人員 & $\begin{array}{l}\mid \text { 霍患 } \\
\text { 数 }\end{array}$ & $\%$ & 人員 & $\mid$ & $\%$ \\
\hline & 23 & 2,460 & 942 & 8.29 & 1,217 & 453 & &, 243 & 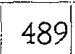 & ה.רנן \\
\hline & & 1,776 & 359 & 20.21 & 907 & 171 & & 869 & 188 & 21.6 \\
\hline
\end{tabular}

表 2 利根郡下斑状歯保有量 (とくに最高最底部落)

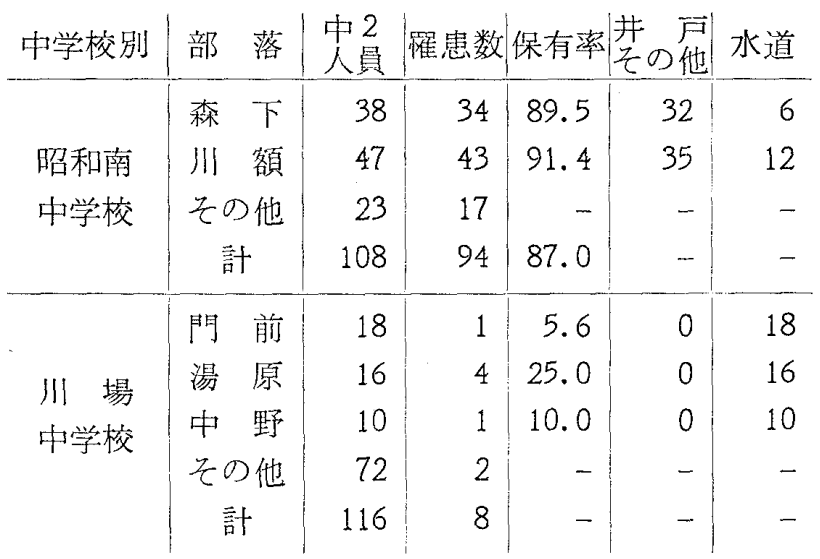

表 1 は利根郡预よび吾妻郡について中学二年生全員に ついてであり，表 2 は利根郡下の最高最低部落別の罪患 状況を示したものである。篗患率のたかい昭和村南中学 校に扮いては $\mathrm{M}_{1} 53.23 \%, \mathrm{M}_{2} 20.97 \%, \mathrm{M}_{3} 1.61 \%$ ， $\mathrm{M}_{1} \mathrm{~B} 1.61 \%, \mathrm{M}_{2} \mathrm{~B} 4.84 \%, \mathrm{M}_{ \pm} 4.84 \%$ が男子で，女 于は $\mathrm{M}_{1} 58.70 \%, \mathrm{M}_{2} 19.56 \%, \mathrm{M}_{ \pm} 6.52 \%$ である。

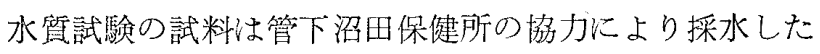
ものと現地調查時に採水したものである。分析方法は文 献 2〜4による。0〜10才の学童が飲用していたのは井 水, 清水で, 10〜15才の学童生徒が飲用していたのは 簢易水道水である。水質試絤は, 今回は主に利根郡につ いて执こない，とくに䍜患率の高い昭和村について現地 調查を行った結果は表3の通りである。以上の結果より 昭和村簡易水道水上りも井水のほらがあさらかに弗紊含 有量が多いことがわかった。那素の分析と同时苚ほかの
表 3 分 析表

\begin{tabular}{|c|c|c|c|}
\hline 採水場所 & 弗 素 & 採水場 所 & 弗 素 \\
\hline 森下井戸水 & $\begin{array}{c}\text { ppm } \\
1.20\end{array}$ & 滝の沢 簡 易 & $\begin{array}{l}\mathrm{ppm} \\
0.30\end{array}$ \\
\hline 吹 張 & 0.60 & 晹原谷地(1)" & 0.20 \\
\hline 平 川 & 0.40 & $(2) " 1$ & 0.39 \\
\hline 追 具 & 0.75 & (3) $" 1$ & 0.10 \\
\hline 木賊 流 水 & 0.50 & (4) "I & 0.15 \\
\hline 門前井戸水 & 0.40 & 東小川 & 0.15 \\
\hline 湯 原 & 0.75 & 鎌 田 & 0.10 \\
\hline 森下簡易水道水 & 0.60 & 土 出 & 0.25 \\
\hline 関屋 & 0.35 & 片品川 上 流 & 0.45 \\
\hline 糸井 & 0.35 & " 下 流 & 0.50 \\
\hline " (宿) " & 0.40 & 薄根川 & 0.30 \\
\hline 平川 " & 0.50 & 利根川 & \\
\hline 追 貝 & 0.18 & （薄根川合流点） & \\
\hline 平沢 & 0.25 & & \\
\hline 川東 & 0.15 & & \\
\hline
\end{tabular}

\begin{tabular}{|c|c|}
\hline & 相 関 関 係 \\
\hline $\mathrm{Cl}-\mathrm{Hardness}$ & $\gamma 20=+0.886$ \\
\hline $\mathrm{C} 1-\mathrm{F}$ & $\gamma 20=+0.645$ \\
\hline $\mathrm{Cl}-\mathrm{SO}_{4}$ & $\gamma 19=+0.456$ \\
\hline Hardness $-\mathrm{SO}_{4}$ & $\gamma 19=+0.620$ \\
\hline F-Hardness & $\gamma 20=+0.827$ \\
\hline $\mathrm{F}-\mathrm{SiO}_{2}$ & $\gamma \rightarrow 0$ \\
\hline F-Alkalinity & " \\
\hline $\mathrm{SiO}_{2}-\mathrm{Alkalinity}$ & " \\
\hline
\end{tabular}

イオンの分析試みたが，弗素イオンと汪かのイオンと の相関関係を表 4 に示方。以上の結果より(1)斑状菡罹患 率と领料水中の弗素の含有量との間には推計学的にも有 意の差があることが明ら方にされ，弗素の含有量の少な い地区でも $\mathrm{M}_{1}$ の患者が多くみられる。これは泀かの因 子にもよると思われる。(2)各イオン間の相関関係をみる と弗素, 塩素イオンおよび総硬度の間には正の相関関係 があるのでこれらは地質学的飞も同一の供給源に由来

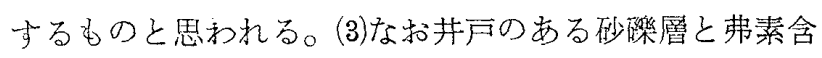
有量の関連や, 斑状歯罪患率とDMF率との関連につい てもあわせてまとめたい。また斑状歯曜患率と高血压症 との関䋆についてb調查をすす奴い。(37.7.26) 


\section{文献}

1) 米沢和一他：日本齿科医師会雑誌 8.3 (昭31)

2）薬学会協定 : 衛生試験法
3) 水道協 会：上水試験法

4) Stephen Megregian: Anal Chem. 20, 1161 (1954)

\section{ガスクロマトグラフィーによる催眠薬の分析 （裁判化学試験法の改良研究 I)}

\section{東北大学医学部薬学科 内山 充, 奥井 誠一}

催眠薬の裁判化学的試験には, 検体より溶媒抽出後結 晶を分離して融点を測定したり，升華させて結晶を鏡検 したりするかペーパークロマトグラフィーで同定 ${ }^{12} し$ たあと必要あれば紫外部吸収スペクトル2)を測定して判 定している。しかし検体のなか存在する薬物がまった く不明であるとき，また性微量の試料を用いて多数の構 造類似体の中のいずれであるかを確認する必要のあると き，試歌方法の選択になょうことが多い。

これらの分析を行らにあたり予試験的な意味で総合的 な検索を行らことができればきわめて便利である。また 上記各種の分析法によっても，なお確䇅の困難なものた とえば methyprylon (Noctan), glutethimide (Doriden）については積極的な確認方法が必要である。以 上の要求を満足させうる手段としてガスクロマトグラフ イーを応用し良好な結果を光だ)。

\section{実験方法}

供試薬骭はバルビッール系 7 種, 非バルビッール系 3 種, 各抒の拈の䄪 $20 \mu \mathrm{g}$ をアセトン $1 \sim 2 \mu \mathrm{l}$ に溶かし たもの。

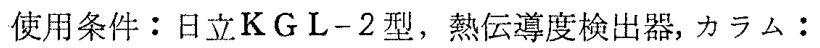
GE silicone SE-30 $25 \mathrm{w} / \mathrm{w} \%$ on Celite 545 (80-100 mesh), 温度 $245^{\circ}$ 付近, He $60 \mathrm{ml} / \mathrm{min}$

\section{実験結果}

Table I 亿表示す。

\section{考察}

充填剤としては silicone SF-96, silicone rubber 等も試㖃したが SE-30 が最良である。溶出温度は $245^{\circ}$ 付近が retention time が適当である。ただしこの条件で は carbamate 系の薬物(ethynamate, meprobamate 等)は retention timeがみじかすぎたり，明膫なピーク が現われなかったりして良好な結果がえられない。この 場合の温度, 吸着剂などについては現在検討中である。 retention time は温度または流速に上り变化与る。 しかし同一種の充埧剤では各薬剂のrelative retention time はお抒のの一定の值となる。したがって未知検体 についてつ衫ね゙ Hexobarbital とともに分析声机ば

\begin{tabular}{|c|c|c|c|}
\hline \multirow[t]{2}{*}{ Table } & \multicolumn{2}{|c|}{$\begin{array}{l}\text { I } \\
\text { Retention } \\
\text { Time }^{\Delta}\end{array}$} & \multirow{2}{*}{$\begin{array}{l}\text { Relative } \\
\text { Retention } \\
\text { Time* }\end{array}$} \\
\hline & $241^{\circ}$ & $247^{\circ}$ & \\
\hline Ethynamate & $\begin{array}{c}\min \\
0.65\end{array}$ & $\min$ & 0.1 \\
\hline Barbital & 2.5 & & 0.36 \\
\hline Methyprylon(Noctan) & 3.1 & 2.8 & 0.45 \\
\hline Diallyl barbituric acid & 3.3 & & 0.47 \\
\hline Amobarbital & 4.4 & & 0.63 \\
\hline Pentobarbital & 5.1 & 4.6 & 0.73 \\
\hline Hexobarbital & 7.0 & 6.3 & 1.00 \\
\hline Thiopental & 7.5 & & 1.07 \\
\hline Glutethimide (Doriden) & 7.55 & & 1.08 \\
\hline Cyclobarbital & 9.4 & & 1.34 \\
\hline
\end{tabular}

* Hexobarbital を 1.00 とした。

$\triangle 247^{\circ}$ のデーターは胃内容物検体上り抽出した例であ る。

その值から直ちに物質の推定を行らことができる。しか るのち純品と混合して再クロマトを行らか䢥当なペーパ 一クロマトを併用することにより確定しらる。

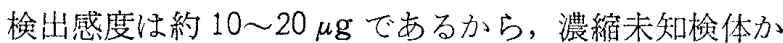
ら明膫なピークの兄られない場合は上記群内の薬剤が含 有されている可能性はきわ好てない。この上らにガ スクロマトグラフィーによる分析法はこれらの催腿薬を 積極的に確認する以外飞，不存在の証明にも用いられ手 軽で確実である。

な扮 methyprylon には現在まで適当なペーパクロマ トグラフィー用発色剂がなかった。东た微量の methyprylon の再結晶は困難である。したがってがスクロマ トグラフィーが methyprylon 確認にはもっともよい手 段であるといえる。

(37. 7)

\section{文献}

1) A.S. Curry: J. Pharmacol., 7, 604 (1955)

2) T.C. Butler: J. Pharmacol., Epx. Therap., 116,326 (1956)

3）本橋投稿中 K.D. Parker, P.L. Kirk はAnal, Chem. 33, 1378 (1961) にバルビッール酸誘導体 23種についてガスクロマトグラフィーによる分析法 を発表した。 